\title{
EXPRESSION AND BIOLOGICAL ACTIVITY OF GHRELIN, OBESTATIN, AND LEPTIN IN DEFERENT DUCTS OF THE BULL AND RAM
}

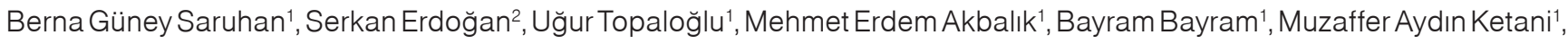 \\ Hakan Sağsöz $z^{1}$ \\ 'Department of Histology and Embryology, Faculty of Veterinary Medicine, Dicle University, 21280 Diyarbakir, ${ }^{2}$ Department of Anatomy, \\ Faculty of Veterinary Medicine, Namık Kemal University, 59030 Tekirdağ, Turkey \\ *Corresponding author, E-mail: hakansagsoz@hotmail.com, hakan.sagsoz@dicle.edu.tr
}

\begin{abstract}
It is known that ghrelin, obestatin and leptin are involved in many biological processes such as appetite-energy regulation, growth hormone release and cell proliferation. In addition to these biological activities of in human and rodents, direct effects of these hormones on reproductive functions and regulation of smooth muscle contractions have gained importance in recent years. In mammals, gonadal functions are regulated by using a complex network of autocrine, paracrine and endocrine signals. The signals involved in the control of energy balance regulate reproductive functions by acting on different hypothalamic pituitary-gonadal axis. The underlying molecular mechanism of gonad is poorly understood and appears to be controlled on genetic, environmental, and hormonal factors. Ghrelin, obestatin and leptin, three recently discovered hormones, are especially coexpressed in endocrine cells. The purpose of this investigation was to examine the immunohistochemical expression and potential biological activity of bull and ram deferent ducts (DD) in relation to the tissue concentration of ghrelin, obestatin and leptin. Ghrelin, obestatin and leptin expression observed in the DD sections were restricted to the cytoplasm of the epithelial and muscle cells. Both ghrelin and leptin expressions were found in smooth muscle cells in muscular layer of DD and smooth muscle cells of blood vessels, and obestatin expression was found in the basal epithelial cells of the luminal epithelium. In conclusion, ghrelin, obestatin and leptin were expressed in varying concentrations in epithelial and muscle cells as well as blood vessels of the deferent ducts of both species. Given the multifunctional biological roles of these peptide hormones, we can suggest that these hormones function in the contraction and hypertrophy of smooth muscles, proliferation or apoptosis of epithelial and muscle cells in DD.
\end{abstract}

Key words: deferent ducts; ghrelin; leptin; obestatin; ruminant; physiological function

\section{Introduction}

In mammals, gonadal functions are regulated by using a complex network of autocrine, paracrine and endocrine signals (1). The central and peripheral endocrine signals involved in the control of energy balance regulate reproductive functions by acting on different hypothalamic pituitary-gonadal axons, thus they linkup between energy homeostasis and fertility (2).

Received: 8 September 2017

Accepted for publication: 4 May 2018
Ghrelin, an orphigenic peptide that regulates energy homeostasis, is an endogenous 28 amino acid ligand of the growth hormone secretagogue receptor (GHS-R) (3). Ghrelin was first reported to be excreted from the stomach and it is localized in many peripheral organs including the brain, kidney, pancreas, placenta, ovary, uterus and testis together with GHS-R $(4,5,6)$. In addition, ghrelin is a hormone that stimulates food intake by acting with the hypothalamus. This hormone also fulfills multiple endocrine and non-endocrine functions such as regulation of cardiovascular functions and metabolic events such as gastric 
motility and acid secretion, glucose regulation and insulin secretion, and cell proliferation $(1,7)$. In recent years, some researches have also reported that ghrelin is involved in the regulation of lactation, pregnancy and reproductive functions, and gonadal activities are critically affected by local expression of ghrelin and its receptor $(8$, 9). In particular, ghrelin may affect the male reproductive axis in situations such as energy deficiency (10). Another hormone that participates in the gonadal axis and metabolic regulation is obestatin (11). Obestatin is a 23 amino acid peptide hormone produced by the gastrointestinal tract. It is produced by the enzymatic division of pre-pro-ghrelin (12). Besides, this hormone is also synthesized from the liver, pancreas, adipose tissue, spleen and mammary gland (6, 9). The function of obestatin in the body is still controversial.

In recent studies, obestatin and ghrelin have been reported to play a functional role in the regulation of metabolic and reproductive functions together. Obestatin and ghrelin, which play a key role in growth axis and body weight homeostasis, partly regulate reproductive function by paracrine or autocrine pathways. In general, obestatin and ghrelin are functional antagonists of each other (9). Afsar et al. (14) have shown that obestatin activates releasing of growth hormone $(\mathrm{GH})$ in contrast to ghrelin in their in vitro studies.

Leptin, a 167 amino acid hormonal protein of the obesity gene, is a polypeptide hormone in the single chain form. It is produced mainly in adipocyte and regulates normal sexual maturation and reproductive functions by autocrine and paracrine effect. It is also synthesized from the liver, stomach, mammary gland, bone marrow, bowel, ovary, testis, skeletal muscle, placenta and fundus of stomach. It is also involved in regulation of food intake and energy balance. Moreover, leptin promotes development of reproductive organs and positively affects the reproductive activity in males $(13,14)$.

Following spermatogenesis in mammals, spermatozoa pass through the efferent channels and leave from the testis, and come into epididymis. Spermatozoa undergo post-testicular maturation phases such as mobility and capacitation in the epididymis. During the ejaculation phase, a spermatozoon passes through the urethra by rhythmic contractions of the deferent duct (DD) (15).
The histomorphological structure of DD has already been investigated in detail in various mammalian species $(15,16,17)$. On the other hand, studies on the expression of gherelin, obestatin and leptin in the male genital tract are quite limited in all mammalian species including human, and these studies have mostly focused on testis and epididymis. Studies of the expression and localization of these factors in DD are limited mostly to humans and rats (16), and only little information is available for other species. In this context, we have detected no study of the cellular localization and expression of ghrelin, obestatin and leptin in bull and ram. Therefore, the aims of the present study were to identify the localization and expression of these peptide hormones in the bull and ram DD by using immunohistochemistry to help us better understand their physiological roles in these two species, and to compare possible differences regarding other species $(18,19,21,22)$.

\section{Materials and methods}

\section{Tissue samples}

In the study, samples of eight healthy and adult bulls and eight rams, which were slaughtered in local slaughterhouses in Diyarbakir province, were used. Samples were fixed in the Bouin's fixative for 12 hours, passed through graded series of ethanol, methyl benzoate and benzene, and finally embedded in paraffin wax. Serial sections containing at least three tissue samples with a thickness of $5 \mu \mathrm{m}$ were cut from each paraffin block (17). Three slides were prepared to demonstrate ghrelin, obestatin and leptin expressions immunohistochemically.

\section{Immunohistochemistry}

The Avidin-Biotin-Peroxidase Complex (ABCcode: 85-9043, Histostain Plus Bulk Kit, Zymed, South San Francisco, CA, USA) procedure was used for the immunohistochemical staining method. Following the deparaffinization and rehydration of the slides, the sections were washed in distilled water. Sections were incubated with $3 \%$ hydrogen peroxide prepared with methanol for $30 \mathrm{~min}$ for the inactivation of endogenous peroxidase, and washed with $0.01 \mathrm{M}$ phosphate buffered saline (PBS; pH 7.4) for $3 \times 5$ min. Sections were boiled 
in citrate buffer ( $\mathrm{pH}$ 6.0) solution for $20 \mathrm{~min}$ for antigen retrieval in the microwave. They were cooled and washed in (PBS) for $3 \times 5$ min. Prior to the addition of the primary antibodies, the slides were incubated with a blocking UltraVision blot (Ultra V Block, Histostain Plus Bulk Kit; Zymed) for 15 min to block non-specific binding. The samples were then incubated with $1 / 100$ diluted anti-ghrelin primary antibody (Rabbit polyclonal to GhrelinAnti-Ghrelin antibody, Abcam, cat no: ab129383), 1/200 diluted anti-obestatin primary antibody (Rabbit polyclonal to Obestatin- Antibody, cat no: ab41704) and 1/100 diluted anti-leptin primary antibody (Rabbit polyclonal to Leptin Anti-Leptin antibody, cat no: ab117751) overnight at $+4^{\circ} \mathrm{C}$. At the end of the incubation period, the sections were washed in $0.01 \mathrm{M}$ PBS for $3 \times 5 \mathrm{~min}$. Then, sections were incubated with biotinylated secondary antibody for $20 \mathrm{~min}$ at room temperature and washed in $0.01 \mathrm{M}$ PBS for $3 \times 5 \mathrm{~min}$. Sections were incubated with streptavidin-peroxidase (HRP) for $20 \mathrm{~min}$ and washed in $0.01 \mathrm{M}$ PBS for $3 \times 5 \mathrm{~min}$, followed by incubation in the diaminobenzidine (DAP) chromogen for 5-10 $\mathrm{min}$ to demonstrate antigen-antibody reactions, washed with distilled water and counterstained with Gill's Hematoxylin for 2 minutes. After passing through the ethanol series and dehydrated, the sections were cleared with xylene and covered with mounting medium (1079610-500-Merck) (18) and cover slips. The specificity of immunohistochemical procedures was assessed using negative and positive control. Stomach (abomasum) sections of bull and ram were used as positive controls. For the negative controls, the slides were incubated with PBS instead of the primary antibodies. All samples were treated with an identical protocol. The slides were photographed by using research microscope Nikon Eclipse E400 (Nikon, Tokyo, Japan) equipped with a digital camera (Nikon Coolpix 4500).

\section{Semiquantitative evaluations}

Immunoreactivities of ghrelin, obestatin and leptin were determined by semiquantitative scoring method (IS) based on the staining intensity $(18,19)$. IS reflected the positive staining intensity in the membranes, cytoplasm and nuclei of the cells. Staining intensity scores were evaluated as follows: - negative; + weak; ++ moderate; +++ strong. The IS of the immunostaining reactions in the cells was evaluated by two independent investigators (B.G.S., H.S.) and the average score of the two observers was estimated. The expressions of ghrelin, obestatin and leptin in the DD were observed at $\mathrm{x} 20$ and $\mathrm{x} 40$ magnifications. Three randomly selected areas for each section were evaluated in each region of the DD (epithelium, connective tissue, muscle and adventitia). Furthermore, following the independent evaluation of the immunohistochemical staining, kappa (k) statistics was used to determine interobserver agreement. Inter-observer variability was estimated by comparing the visual scores of two researchers. The results were presented separately for epithelial cells, stromal cells, muscle cells, blood vessels and nerves.

\section{Results}

Ghrelin, obestatin and leptin immunoreactivities, which were observed in the DD sections of bulls and rams were restricted to the cytoplasm of epithelial and muscle cells. Immunoreaction was observed for ghrelin, obestatin and leptin in the positive controls, while no staining was determined in the negative controls (Figs. 1a,b,c).

Ghrelin. In bulls and rams, ghrelin was strongly expressed in the longitudinal and circular muscular layers of DD and media layer of blood vessels. On the contrary, ghrelin expression was not observed in the luminal epithelium, stromal cells, and nerve plexus in both species (Figs. 2a,b,c and 3a, b) (Table 1).

Obestatin. Expression was strong in the basal cells of the luminal epithelium in both bulls and rams, but weak in the ciliated epithelial cells. In addition, there was a weak expression of obestatin in the connective tissue cells surrounding the adventitial layer of DD in both species. Obestatin immunoreactivity was not determined in the smooth muscle cells of muscular layer, stromal cells of DD and nerve plexuses (Figs. 4a,b and $5 a, b, c)$ (Table 1).

Leptin. In bulls and rams, leptin expression was fairly strong in smooth muscle cells of media layers of blood vessels and muscular layer of DD, and it was moderate in some stromal cells. On the other hand, leptin expression was not detected in luminal epithelial cells, the cells surrounding the adventitia, and nerve plexuses (Figs. 6a,b and $7 a, b)($ Table 1). 

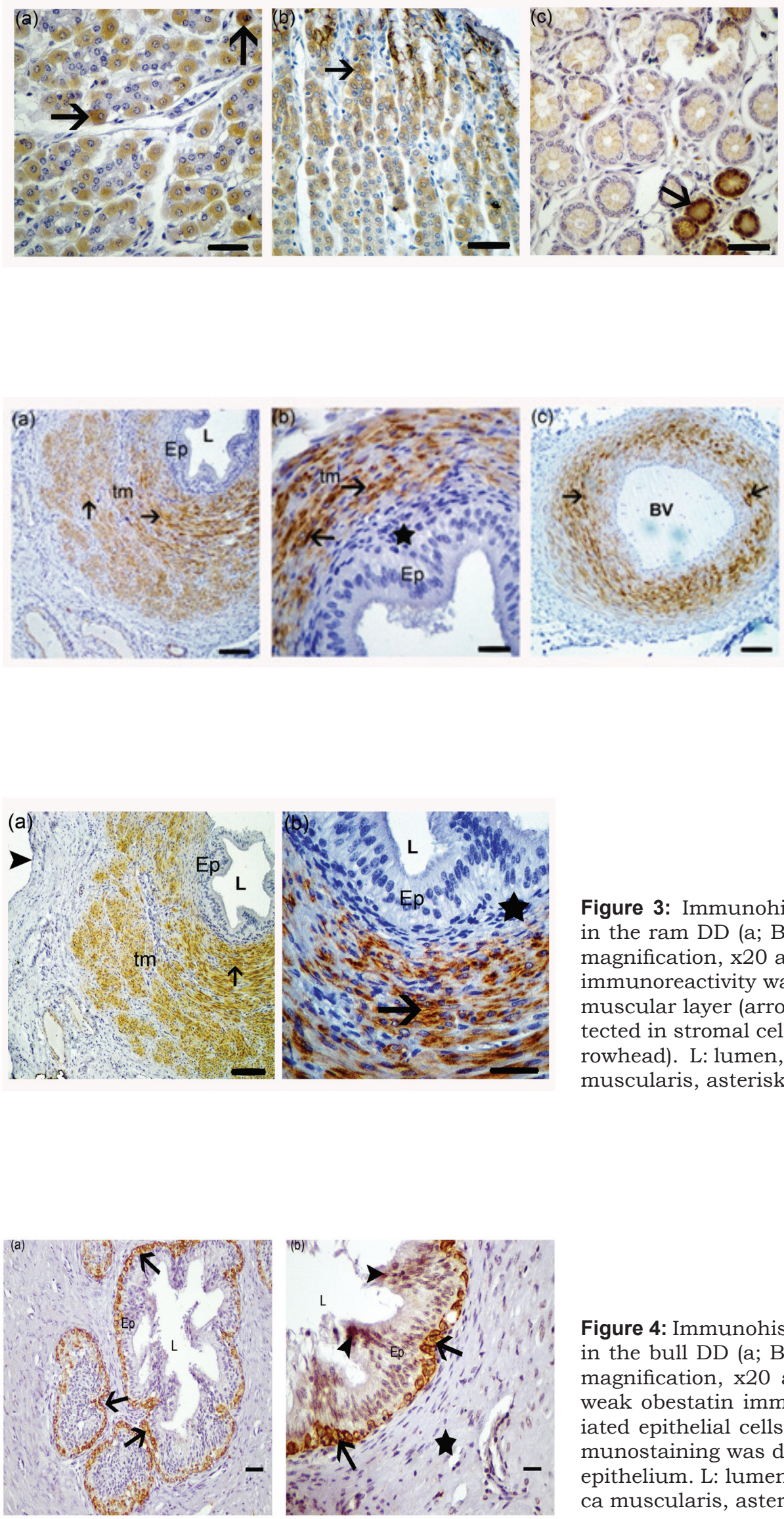

Figure 4: Immunohistochemical expression of obestatin in the bull DD (a; Bar: $50 \mu \mathrm{m}$, b; Bar: $25 \mu \mathrm{m}$, original magnification, $\mathrm{x} 20$ and $\mathrm{x} 40$, respectively). (a,b) While weak obestatin immunoreactivity was observed in ciliated epithelial cells (arrowhead), strong obestatin immunostaining was detected in basal cells (arrow) of the epithelium. L: lumen, Ep: luminal epithelium, tm: tunica muscularis, asterisk: stroma 
Figure 5: Immunohistochemical expression of obestatin in the ram DD (a-c; Bar: $50 \mu \mathrm{m}$, b; Bar: $25 \mu \mathrm{m}$, original magnification, x20 and x40, respectively). (a,b) Obestatin immunoreactivity was strongly expressed in basal cells (arrow) of luminal epithelium; (c) Weak obestatin immunostaining was observed in smooth muscle cells (arrow) of blood vessels. L: lumen, Ep: luminal epithelium, tm: tunica muscularis, BV: blood vessel, asterisk: muscle layer
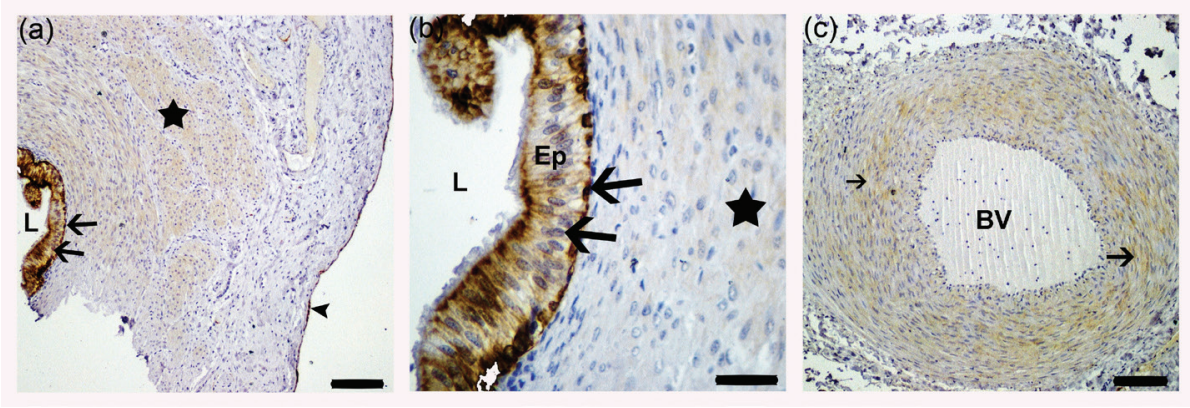

Figure 6: Immunohistochemical expression of leptin in the bull DD (a; Bar: $50 \mu \mathrm{m}$, b; Bar: $25 \mu \mathrm{m}$, original magnification, x20 and x40, respectively). (a,b) Strong leptin immunoreactivity was observed in smooth muscle cells (arrow) of muscular layer. L: lumen, Ep: luminal epithelium, tm: tunica muscularis, asterisk: stroma
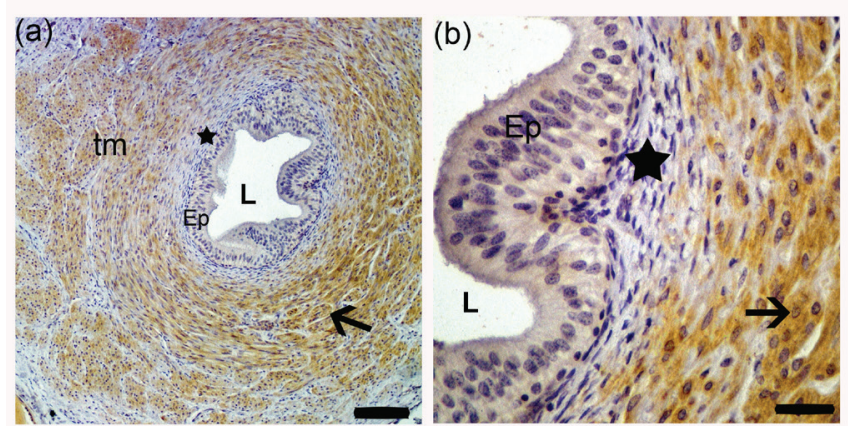

Figure 7: Immunohistochemical expression of leptin in the ram DD (a; Bar: $25 \mu \mathrm{m}$, b; Bar: $50 \mu \mathrm{m}$, original magnification, $\mathrm{x} 40$ and $\mathrm{x} 20$, respectively). (a) Strong leptin immunostaining was detected in smooth muscle cells of muscular layer (thick arrow); (b) Strong leptin immunoreactivity was determined in endothelial (arrowhead) and smooth muscle cells (thin arrow) of the blood vessels. L: lumen, Ep: luminal epithelium, tm: tunica muscularis, BV: blood vessel, asterisk: stroma

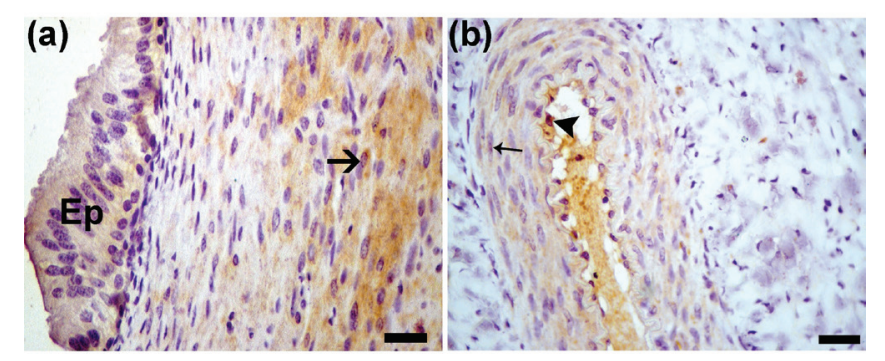

Table 1: Scoring for immunostaining of ghrelin, obestatin and leptin in the bull and ram deferent ducts

\begin{tabular}{|c|c|c|c|c|c|c|c|c|}
\hline \multirow{3}{*}{ Antibodies } & \multirow{3}{*}{ Animals } & \multicolumn{4}{|c|}{ Ductus Deferens } & \multicolumn{2}{|c|}{ Blood vessels layers } & \multirow{3}{*}{$\begin{array}{l}\text { Nerve } \\
\text { plexuses }\end{array}$} \\
\hline & & \multicolumn{2}{|c|}{ Tunica mucosa } & \multirow{2}{*}{ Tunica muscularis } & \multirow{2}{*}{ Adventitia } & \multirow{2}{*}{ İntima } & \multirow{2}{*}{ Media } & \\
\hline & & Epithelium & Stroma & & & & & \\
\hline \multirow{2}{*}{ Ghrelin } & Bull & - & - & +++ & - & - & +++ & - \\
\hline & Ram & - & - & +++ & - & - & +++ & - \\
\hline \multirow{2}{*}{ Obestatin } & Bull & +++ & - & - & + & - & - & - \\
\hline & Ram & +++ & - & - & + & - & - & - \\
\hline \multirow{2}{*}{ Leptin } & Bull & - & ++ & +++ & - & +++ & +++ & - \\
\hline & Ram & - & ++ & +++ & - & +++ & +++ & - \\
\hline
\end{tabular}

Staining intensity: - negative, + weak, ++ moderate, +++ strong 


\section{Discussion}

In the present study, we showed that both ghrelin and leptin expressions in bulls and rams are strong in muscular layer of DD and smooth muscle cells of blood vessels. On the contrary, obestatin expression is strong in the basal epithelial cells of the epithelial layer. Fertility is controlled by a multi-hormonal effect in all mammals. Any functional defect in the components of this hormonal complex directly affects the reproduction. Recent researches have revealed that ghrelin, obestatin and leptin produced from the adipose tissue and gastrointestinal tract are new members of this hormonal complex. These hormones acting on hypothalamic-pituitarygonadal axis cause various effects on reproductive functions as well as carbohydrate and fat metabolism and have effects on appetite (20).

The epididymis and DD, part of the epididymis, are a crucial region for the maturation of sperm. It is plausible that these peptides that meet the sperm before their access to the epididymis may influence post-gonadal sperm modifications, such as motility, egg binding and penetration (18). In support, clues on the influence of ghrelin, obestatin and leptin on rat and human sperm motility are available in the literature $(18,19,21,22)$. It was reported that ghrelin and obestatin originate from the same gene, even though in different tissues (18). This discovery could support, at least in part, our observation that ghrelin and obestatin are not necessarily expressed together, as observed in epididymis.

In some studies, correlation and localization results among ghrelin, obestatin and leptin expressions in testicular cells, and the effects of each peptide on reproduction have led to the production of diverse ideas (14). There are studies on the localization and functions of ghrelin, obestatin and leptin in female and male genital systems of mammals including humans $(14,18,19)$. However, these studies have mostly focused on the female genital tract $(1,2)$. Studies on ghrelin, obestatin and leptin in the male genital system have been focused on testis and epididymis in humans and rats $(14,18,21,22)$. A limited number of studies on the localization and biological functions of these peptide hormones have been found in the testes and epididymis in domestic mammals (19).
Ghrelin is expressed by Leydig and Sertoli cells of testis and this hormone can regulate spermatogenesis by autocrine and/or paracrine pathways (21). In rats, ghrelin expression was positive in the apical parts of epithelial cells of the seminal vesicle, and was negative in the connective tissue (23). In addition, it has been reported that ghrelin has a strong expression in the epithelial cells of the efferent ducts of the human epididymis, whereas there is no immunoreaction in its connective tissue (19). Moretti et al. (18) detected moderate level of ghrelin in DD and in few epithelial cells of the seminal vesicle in humans. In our study, ghrelin expression was limited by smooth muscle cells in the muscular layer of DD and smooth muscle cells in the media layer of the blood vessels in both bull and ram. In contrast to Moretti et al. (18) reports in humans, ghrelin expression was not found in epithelial cells of DD in bull and ram (Table 1).

According to recent studies, ghrelin has an effect on smooth muscle cells and accelerates gastric emptying (24). In humans, ghrelin has been described to be responsible for tonus of uterine smooth muscles and contractility (25). Qiu et al. (26) and Asakawa et al. (27) found that ghrelin administration in mice with experimental diabetes produced spontaneous increased contractions in smooth muscles by the activation of peripheral cholinergic pathways. In one study, ghrelin also affected different systems such as muscle motility and cell proliferation (28). Again, ghrelin stimulated and strengthened the contractions in the muscles in rats, mice, and guinea pigs (29). Deferent duct has a structure consisting of thick smooth muscles that makes powerful peristaltic movements during ejaculation, allowing the spermatozoa to flush out (30). In the present study, the expression of ghrelin that was found only in smooth muscle cells of DD, suggest that ghrelin may have the main role in stimulation of smooth muscle contractions during ejaculation in bulls and rams.

Although the testicular expression of obestatin in different cell types has been reported, the role of this peptide hormone in the male genital tract is still poorly understood (14). Dun et al. (31) and Moretti et al. (18) reported an intense expression of obestatin in DD, efferent duct and epithelial cells of seminal vesicle in rats and humans. In another study, obestatin was weakly expressed from apical cytoplasm of epithelial cells of seminal vesicle, 
and it was not found in the connective tissue (23). As reported in the aforementioned studies $(18,23$, 31 ), obestatin was positive in epithelial cells in DD and negative in stromal cells, and but it was released only from basal cells in bulls and rams. Previous studies have suggested that obestatin may play a role in cell proliferation, regulation of apoptosis and epithelial cell function. Our study suggests that intense expression of obestatin, especially in epithelial basal cells, may be associated with increasing epithelial proliferation and differentiation in these stem cell-treated cells.

In the 90s, the discovery of leptin was a major development about human metabolism, and it has been demonstrated that leptin has also played an effective role in the human reproduction (32). Leptin has direct effects on fertility in both male and female rodents, and it can reverse the infertility in ob / ob mice lacking the leptin gene (19). In some studies, a number of functions in male genital organs are regulated by leptin via the central nervous system. In recent years, it has been suggested that this hormone has a direct environmental effect on the target reproductive organs (22). In pigs, leptin expression was negative in immature genital duct epithelial cells and moderately positive in matures. In mice, leptin regulated the proliferation and differentiation of testicular germ cells (19). Studies in humans and laboratory animals have shown that leptin plays a key role by increasing muscle mass and myofibrilar hypertrophy in the musculature system (33). Leptin promotes proliferation in vascular smooth muscle cells by stimulating the transition from $\mathrm{G} 1$ phase to $\mathrm{S}$ phase during cell division, and ERK1 / 2 and NF-kB pathways support this process $(34,35)$. In our study, leptin expression was not found in the epithelium of DD, and it was found especially in the media layers of blood vessels and smooth muscle cells. This suggests that leptin increases muscle mass and hypertrophy in smooth muscle cells of DD in bull and ram. Besides, expressions in blood vessels also supports that this peptide hormone may play a role in the proliferation of vascular smooth muscle cells. Based on our results we can suggest that leptin has also a role in physiology of stromal cells in DD.

In mice and rats, leptin and ghrelin are expressed in endothelial and smooth muscle cells of blood vessels, but vascular effects of these two peptide hormones are not clear. The authors have stated that ghrelin and leptin may function in the regulation of vasodilatation, vasoconstriction or vascular permeability in blood vessels $(36,37)$. In the present study, we determined that ghrelin and leptin were expressed in the blood vessels localized in DD of bulls and rams.

In conclusion, ghrelin, obestatin and leptin were expressed in varying concentrations in epithelial, stromal and smooth muscle cells of the bull and ram DD. We can suggest that these hormones function in the contraction and hypertrophy of smooth muscles, and maybe in proliferation or apoptosis of epithelial and stromal cells in DD, too. However, we believe that we need more data to understand better the mechanisms that regulate the expressions and functions of ghrelin, obestatin and leptin in different layers of DD.

\section{Acknowledgement}

Contributors: HS planned the study, designed the experiments and wrote the manuscript; BGS helped with data analyses, bioinformatics and manuscript writing; MEA, SE, UT and BB collected samples and conducted laboratory process; MAK analyzed the statistical data. All authors read and approved the final manuscript.

Conflicts of interest: The authors declare that they have no conflict of interest.

Funding: This research did not receive any specific grant from funding agencies in the public, commercial, or not-for-profit sectors.

\section{References}

1. Fernández-Fernández $R$, Tena-Sempere $M$, Aguilar E, Pinilla L. Ghrelin effects on gonadotropin secretion in male and female rats. Neurosci Lett 2004; 362: 103-7.

2. Fernández-Fernández R, Tena-Sempere M, Navarro VM, et al. Effects of ghrelin upon gonadotropin-releasing hormone and gonadotropin secretion in adult female rats: in vivo and in vitro studies. Neuroendocrinology 2005; 82: 245-55.

3. Yang J, Brown MS, Liang G, Grishin NV, Goldstein JL. Identification of the acyltransferase that octanoylates ghrelin, an appetite-stimulating peptide hormone. Cell 2008; 132: 387-96.

4. Tanaka K, Minoura H, Isobe T, et al. Ghrelin is involved in the decidualization of human 
endometrial stromal cells. J Clin Endocrinol Metab 2003; 88: 2335-40.

5. Sönmez MF, Ozan E. Determination of ghrelin immunoreactivity in the rat stomach after fasting and refeeding. Acta Histochem 2007; 109: 193-9.

6. Unsal F, Sönmez MF. The effects of ovariectomy on ghrelin expression in the rat uterus. Adv Clin Exp Med 2014; 23: 363-70.

7. Jeffery PL, Herington AC, Chopin LK. The potential autocrine/paracrine roles of ghrelin and its receptor in hormone-dependent cancer. Cytokine Growth Factor Rev 2003; 14: 113-22.

8. Muccioli G, Lorenzi T, Lorenzi M, et al. Beyond the metabolic role of ghrelin: a new player in the regulation of reproductive function. Peptides 2011; 32: 2514-21.

9. Tena-Sempere M. Ghrelin, the gonadal axis and the onset of puberty. Endocr Dev 2013; 25: 69-82.

10. Moshtaghi-Kashanian GR, Razavi F. Ghrelin and leptin levels in relation to puberty and reproductive function in patients with betathalassemia. Hormones (Athens) 2009; 8: 207-13.

11. Nogueiras $R$, Pfluger $P$, Tovar $S$, et al. Effects of obestatin on energy balance and growth hormone secretion in rodents. Endocrinology 2007; 148: 21-6.

12. Caminos J, Tena-Sempere M, Gaytan F, et al. Expression of ghrelin in the cyclic and pregnant rat ovary. Endocrinology 2003; 144: 1594-602.

13. Lin Y, Li Q. The regulation of development and lactation of the mammary gland by leptin. $\mathrm{J}$ Am Sci 2005; 1(1): 63-7.

14. Afsar T, Jahan S, Razak S, et al. Obestatin modulates ghrelin's effects on the basal and stimulated testosterone secretion by the testis of rat: an in vitro study. Physiol Res 2017; 66: 93-8.

15. Mahmud MA, Onu J, Shehu SA, Umaru A, Danmaigoro A, Atabo MS. Morphological studies on epididymis and vas deferens of one - humped camel bull (Camelus dromedarius), uda ram and red sokoto buck. Am J Biosci Bioengineer 2015; 3: 65-71.

16. Nistal M, Santamaria L, Paniagua R. The ampulla of the ductus deferens in man: morphological and ultrastructural aspects. J Anat 1992; 180: 97-104.

17. Saruhan BG, Topaloğlu U, Akbalik ME, Ketani MA, Sağsöz H. The first part of the ductus deferens in bull and ram: morphological, histological and histochemical aspects. Dicle Üniv
Vet Fak Derg 2016; 1: 35-41.

18. Moretti E, Vindigni C, Tripodi S, et al. Immunolocalisation of ghrelin and obestatin in human testis seminal vesicles, prostate and spermatozoa. Andrologia 2014; 46: 979-85.

19. Rago V, Aquila S, Guido C, Carpino A. Leptin and its receptor are expressed in the testis and in the epididymis of young and adult pigs. Anat Rec (Hoboken) 2009; 292: 736-45.

20. El-Eshmawy MM, Abdel Aal IA, El Hawary AK. Association of ghrelin and leptin with reproductive hormones in constitutional delay of growth and puberty. Reprod Biol Endocrinol 2010; 8: e153 (6 p.) https://rbej.biomedcentral. $\mathrm{com} / \mathrm{track} / \mathrm{pdf} / 10.1186 / 1477-7827-8-153$

21. Dupont J, Maillard V, Coyral-Castel S, Rame C, Froment P. Ghrelin in female and male reproduction. Int $\mathrm{J}$ Pept 2010; 2010: e8 Art ID 158102 (8 p.) https://www.hindawi.com/journals/ijpep/2010/158102/

22. Tena-Sempere M, Barreiro ML. Leptin in male reproduction: the testis paradigm. Mol Cell Endocrinol 2002; 188: 9-13.

23. Çatak Z, Aydin S, Sahin I, Kuloglu T, Aksoy A, Dagli AF. Regulatory neuropeptides (ghrelin, obestatin and nesfatin-1) levels in serum and reproductive tissues of female and male rats with fructose-induced metabolic syndrome. Neuropeptides 2014; 48: 167-77.

24. Baran M, Eliaçık K. Etiology and pathogenesis of chronic constipation in childhood. İzmir Dr Behçet Uz ve Çocuk Hast Derg 2013; 3: $12-7$.

25. Georgiev T, Tolekova A, Kalfin R, Hadzhibozheva P. Short-term administration of melatonin or ghrelin on diabetic rats: effects on angiotensin II and vasopressin-induced uterine contractility. Physiol Res 2016; 66: 125-33.

26. Qiu WC, Wang ZG, Lv R, et al. Ghrelin improves delayed gastrointestinal transit in alloxan-induced diabetic mice. World $\mathrm{J}$ Gastroenterol 2008; 14: 2572-7.

27. Asakawa $\mathrm{A}$, Inui $\mathrm{A}$, Kaga $\mathrm{T}$, Yuzuriha $\mathrm{H}$, Nagata T, Ueno N. Ghrelin is an appetite stimulatory signal from stomach with structural resemblance to motilin. Gastroenterology 2001; 120: 337-44.

28. Fak1 Y. Obez tip 2 diabetes mellituslu hastalarda, serum aktive ghrelin hormonunun glisemik kontrol üzerine etkinliği. Istanbul : Ministry of Health Okmeydani Education Research Hospital, 2009: 41-4. Master thesis 
29. Şahin M. Diabetic autonomic neuropathy. KSU Tip Fak Derg 2015; 10: 52-7.

30. Alkafafy M, Attia H, Rashed R, Kandiel M. Some comparative immunohistochemical studies on the ductus deferens in the donkey (Equus asinus) and water buffalo bull (Bubalus bubalis). $\mathrm{J}$ Vet Anat 2010; 3: 55-69.

31. Dun SL, Brailoiu GC, Brailoiu E, Yang J, Chang JK, Dun NJ. Distribution and biological activity of obestatin in the rat. J Endocrinol 2006; 191: 481-9.

32. Israel $\mathrm{D}$, Chua $\mathrm{S}$, Jr. Leptin receptor modulation of adiposity and fertility. Trends Endocrinol Metab 2010; 21: 10-6.

33. Hamrick MW, Herberg S, Arounleut P, et al. The adipokine leptin increases skeletal muscle mass and significantly alters skeletal muscle miRNA expression profile in aged mice. Biochem Biophys Res Commun. 2010; 400: 379-83.
34. Huang F, Xiong X, Wang H, You S, Zeng H. Leptin-induced vascular smooth muscle cell proliferation via regulating cell cycle, activating ERK1/2 and NF-kappaB. Acta Biochim Biophys Sin (Shanghai) 2010; 42: 325-31.

35. Shyu KG, Chen SC, Wang BW, Cheng WP, Hung HF. Mechanism of the inhibitory effect of atorvastatin on leptin expression induced by angiotensin II in cultured human coronary artery smooth muscle cells. Clin Sci (Lond) 2012; 122: 33-42.

36. Callaghan B, Hunne B, Hirayama H, et al. Sites of action of ghrelin receptor ligands in cardiovascular control. Am J Physiol Heart Circ Physiol 2012; 303: 1011-21.

37. Schroeter MR, Schneiderman J, Schumann $B$, et al. Expression of the leptin receptor in different types of vascular lesions. Histochem Cell Biol 2007; 128: 323-33.

\title{
IZRAŽANJE IN BIOLOŠKA AKTIVNOST GRELINA, OBESTATINA IN LEPTINA V SEMENOVODU PRI BIKU IN OVNU
}

\author{
B.G. Saruhan, S. Erdoğan, U. Topaloğlu, M.E. Akbalık, B. Bayram, M.A. Ketani, H. Sağsöz
}

Povzetek: Znano je, da so grelin, obestatin in leptin vključeni vštevilne biološke procese, kot so uravnavanje apetita, sproščanje rastnega hormona in spodbujanje delitev celic. Poleg omenjenih bioloških učinkov priljudeh in glodavcih so v zadnjih letih postali znani tudi njihovi neposredni učinki na delovanje spolnega sistema in uravnavanje kontrakcije gladkih mišic. Pri sesalcih je delovanje spolnih žlez uravnano z zapleteno mrežo avtokrinih, parakrinih in endokrinih sporočil. Sporočila, ki sodelujejo pri nadzoru energetskega ravnotežja $v$ telesu pogosto vplivajo tudi na delovanje spolnega sistema z vplivom na hipotalamusno-hipofizno-spolno os. Osnovni molekularni mehanizem delovanja spolnih žlez je slabo raziskan, na njegovo delovanje pa vplivajo genetski, okoljski in hormonski dejavniki. Grelin, obestatin in leptin so trije hormoni, ki v telesu sodelujejo pri urejanju in ohranjanju energetskega ravnotežja. Namen raziskave je bil preučiti imunohistokemično izražanje in potencialno biološko aktivnost grelina, obestatina in leptina v semenovodu bikov in ovnov. Grelin, obestatin in leptin so izraženi v semenovodu in so bili omejeni na citoplazmo epitelijskih in mišičnih celic. Grelin in leptin sta bila izražena v gladkih mišičnih celicah mišične plasti semenovoda in gladkih mišičnih celicah krvnih žil. Obestatin je bil izražen v bazalnih epitelijskih celicah svetline semenovoda. Grelin, obestatin in leptin so torej izraženi v različnih koncentracijah v epitelnih in mišičnih celicah ter krvnih žilah v semenovodu pri biku in ovnu. Glede na raznolike biološke vloge teh peptidnih hormonov lahko predvidevamo, da ti hormoni morda sodelujejo pri krčenju in hipertrofiji gladkih mišic ter pri množenju ali apoptozi epitelijskih in mišičnih celic v semenovodu.

Ključne besede: semenovod; grelin; leptin; obestatin; bik; oven; fiziološka funkcija 